BÜLENT GÜZEL,

Yildiz Technical University (Istanbul, Turkey)

e-mail: bcguzel@gmail.com,ORCID0000-0001-6915-4209

\title{
ON SELFNESS (THE "I") THE KEY TO THE UNIVERSE
}

\begin{abstract}
According to the retrospective analysis of the prominent representatives of European philosophy regarding knowledge and belief, the author suggests that the Universe is a "receptacle" of knowledge about the world, and one source of the knowledge origin is religion. Moreover, he depicts that the source of ideas' interpretation and new meanings receiving in the Islamic tradition is the collection "Risale-i Nur" written by the Turkish theologian Bediüzzaman Said Nursi. The new distinctive understanding of relations between the Qur'an - the book of "Divine language attribute" and the Universe - the book of "Divine will attribute" is offered in "Risale-i Nur". Bediüzzaman constantly draws attention to the Universe, demonstrates how "to read" it via the Qur'anic methodology, how to understand the eternal sense any that creation points at, and how to come to the conclusions mentioned in the Qur'an. Analysing the particular volumes of "Risale-i Nur" (namely, "The Words", "The Letters", "The Flashes", "The Rays"), the author highlights originality of Said Nursi's considerations that are neither similar to the wisdom of the East nor to the science of the West. "Risale-i Nur" is proved to reveal the conceptual meanings and the true values of the Universe by the direct inspiration of the Qur'an and not merely on the real rational deductions. Having accepted knowledge and observations in the light of pages and words from the book of the Universe, Nursi revealed the direct connection between the Qur'an and the Universe. Thus, he proved that there were not any contradictions between them and factually, they were written by the same author. Consequently, when "selfness" (the "I") is properly involved, it is obvious for a person that the book of the Universe is not different in any way for the revelation. The definitions of Said Nursi exist in four main concepts: one has the sense of the other; every notion contains its definition, intentions and perceptions. When the nature of "selfness" is known and used as described, it offers perceptions that does not reject the products of philosophical and scientific approach and interprets them in the light of revelation, transforming all information into the wisdom. Therefore, the key to deciphering a book of the Universe is in the human nature and its selfness.
\end{abstract}

Key words: selfness; universe; Risale-i Nur; the Qur'an.

\section{Introduction}

Affecting the entire world, COVID-19 Pandemic proves us that the majority of people are belief-driven. Many believed in the existence of a virus which they had not seen or heard about before without a doubt. Despite the fact that the virus itself is invisible to the eye, witnessing the impacts of what has been happening around the world and hearing about reports provided by trusted authorities such as scientists and doctors helped clear the doubts about the virus' existence. Thus, the majority of people were able to make decisions affecting, restricting and leading their lives. In a similar way, although people cannot see the Creator Himself, upon observing His prominent arts and acts all around the universe and hearing the narratives provided by trusted messengers (prophets), the majority of people prefer to shape their lives accordingly. Thinking about our ways of affirming widely accepted theories or entities such as the roundness of the earth, the law of gravity and the existence of black holes, how do we rationally decide what to believe or do? Is it a rational belief or reasonable faith? Do we base our decisions on knowledge and observation only? Humans take an egocentric approach towards everything else but themselves interpreting all knowledge and observation with their ego. Throughout the history of philosophy and religion, there had been a tremendous effort to elucidate the concept of 'self' (e.g. On Nature of Parmenides, Know Thyself in the pronaos of the Temple of Apollo at Delphi, Peri psukhes of Aristoteles, Cogito of Descartes, Geist of Hegel). Psychoanalysts such as Freud, Kohut and Adler put particular emphasis on defining the "self" especially because the words and concepts of "l" and "ego" are the main driving forces in human behavior. They have called it selfconsciousness. By definition, a self-conscious person aims to think of themselves in their actions all the time (Campbell, 1995). With a totally different approach, Bediüzzaman Said Nursi points out that "selfness" is a "key" for man to understand the meaning of the universe and its relation to himself, mainly in deducing from what he observes and experiences, and knowledge he collects. Similar to, yet different from Descartes, according to Nursi, understanding the concept of "selfness" is essential for man to apprehend his Creator. This work examines how "selfness" is analyzed by Bediüzzaman Said Nursi in his Risale-i Nur Collection and how it is defined in the Qur'an.

\section{Methods}

In deciding what to do or what to believe, thinking, beliefs and feelings are the main driving forces of people. After reviewing the evolution of thinking in human history, from mythopoetic thinking in early times to critical thinking in modern times, it is noted that the focus has been turned 
into more concrete issues from the conceptual ones (e.g, answering the question how rather than why) with the rise of empiricism. This shift has increased the significance of knowledge. Advocating the empirical methods further by well-known rationalists like Descartes, Spinoza, and Leibniz (Anstey, 2010), it, in turn, has given rise to the thought that only knowledge can bring one up to the truth, and has led to glorifying and idolizing the science. In contrast, Cartesian approach of relating the individual to the consciousness (I think, therefore I am), Kant's attempts to push the religious concerns out of the borders of knowledge, and Hegel's absolute concept did not work towards a solution. It is the subject of Epistemology to research to what extent the knowledge attained through reasoning is accurate and how the knowledge is obtained by reasoning (theory of knowledge). But the definition of knowledge is always cumbersome. According to Plato's third definition, "Knowledge is justified, true belief". Even now, for the majority, what they call knowledge is just a belief. For example we all know (believe!) that the earth is round even though we cannot prove it on our own. That's because we basically trust the testimony of others. Descartes defined knowledge as follows: "Intuitions provide the ultimate grounds for logical deductions. Ultimate first principles must be known through intuitions while deduction locally derives conclusions from them. These two methods (intuition and deduction) are the most certain routes to knowledge, and mind should admit no others". Today, technically speaking, data (raw facts) turn into information when is processed with reasoning. Information is called knowledge, only if it is combined with some understanding. Thus, repeating a sentence pronounced (e.g. data) without any understanding is just parroting someone else, which is the common practice for the majority. Moreover, in a knowledgebased understanding, whatever falls behind what the eye can see is called metaphysics and is not taken into account at all.

On the other hand, when there is no sufficient information, any interpretation or understanding based on observations will be incomplete. Logical empiricists (e.g. John Locke) suggest obtaining knowledge purely from observation and they believe that all knowledge begins with observation (Loeb, 1981; Russell, 1993). But, this leads to another problem; empirical generalizations among observable entities. Positivism (e.g. John Locke, David Hume) recognizes as valid only the knowledge based on experience. According to Wittgenstein's verification theory (1920), statements or propositions are meaningful only if they can be empirically verified. This view differentiates scientific statements from the metaphysical ones. Unlike positivists, Popper accepted the fact that "observation always presupposes the existence of some system of expectations". According to Kuhn and Popper, observations are always interpreted in the context of a priori knowledge i.e. what a man sees depends both upon what he looks at and also upon what his previous visual-conceptual experience has taught him to see. Therefore, all observation is potentially "contaminated", whether by our theories, our worldview or our past experiences. Induction and deduction are the inseparable parts of our recursive thinking process. We obtain information from observations or experimental results by induction, and then extract common patterns or rules or regularities by deduction. Up until now, there have been many attempts to thoroughly understand the process of creation by observation through induction and deduction methods. But, any explanation is far from defining and making sense of the relation between human beings and the universe because of not being able to answer the question "why". Any statement discussing and answering only the question "how" remains incomplete in terms of understanding the man and the universe as a whole (Heidegger). In this continuum, science has progressed so to satisfy the desires of self, the 'self' has been put into the center of attention, the objective of reasoning has not been realized and desires of self has been justified by reason.

In spite of these complexities in understanding the universe and ourselves, we still live by meanings and try to shape our worlds according to dynamically changing meanings. From observation and information that is transmitted to us by others, we actively construct meanings. Then we construct reality and truth based on that. But information and meaning are not contained in the real world i.e. they don't have physical bodies. They are rather transferred in the forms of words, symbols, images, sounds, objects and likewise. We are always about the search for new meanings where communication is imparting of information and meaning through signs and messages. In that sense, we have another source of knowledge for the meanings; religions.

\section{Results and discussions}

Apart from the other religions, along with the revelations of the Qur'an, there happened a semantical intervention to human thinking. With these new concepts shaping human understanding of selves, the universe and the Creator new meanings emerged. Within the Islamic civilization that has been developing for centuries, Nursi's Risale-i Nur has offered a new understanding following the methodology of Qur'an. For instance, a great number of metaphors are used describing the universe as a display, a farm, a guesthouse, a palace or a factory. Particularly using the metaphor of book, namely something to read, characterizes Risale-i Nur's methodology. In Risale-i Nur, Bediüzzaman puts particular emphasis on the complementary nature of the relationship between the Qur'an - the book of the "Divine attribute of Speech"- and the universe - the book of Power of "Divine attribute of Will" (Nursi, The Rais, 1998). Bediüzzaman constantly draws the attention of readers to the universe showing them how to read it with the Qur'anic methodology, how to grasp the eternal meaning pointed out by the creation and how to reach to the conclusions indicated by the Qur'an. To give a couple of examples:

"Perfect order and balanced harmony can occur only through unity. The order has also transformed the universe into a miraculous book so full of meaning that each of its letters expresses the meanings of a hundred lines, and each of its lines the meanings of a hundred pages, and each of its pages the meanings of a hundred chapters, and each of its chapters the meanings of a hundred books. Moreover, all its chapters, pages, lines, words, and letters look to each other and allude to each other" (Nursi, 29, The Rais, 1998: 38).

"The greatest manifestation of the divine name of Sapient has made the universe like a book in every page of which hundreds of books have been written, and in every line of which hundreds of pages have been included, and in every word of which are hundreds of lines, and in each letter of which are a hundred words, and in every point of which is found a short index of the book. The book's pages and lines down to the very points show its Inscriber and Writer with such clarity that that book of the universe testifies to and proves the existence and unity of its Scribe to a degree far greater than it shows its own existence. For if a single letter shows its own existence to the extent of a letter, it shows its Scribe to the extent of a line. Yes, one 
page of this mighty book is the face of the earth. Books to the number of the plant and animal species are to be observed on this page in the spring, one within the other, together, at the same time, without error, in the most perfect form. A single line of the page is a garden. We see that written on this line are well-composed odes to the number of flowers, trees, and animals, together, one within the other, without error. One word of the line is a tree which has opened its blossom and put forth its leaves in order to produce its fruit. This word consists of meaningful passages lauding and praising the All-Glorious Sapient One to the number of orderly, well-proportioned, adorned leaves, flowers, and fruits. It is as though like all trees, this tree is a well-composed ode singing the praises of its Inscriber." (Nursi, 311, The Flashes, 1998:400)

If so, there is a reciprocal relationship between the Qur'an and the universe. In order to understand the meanings of the universe and find answers to the questions of "why" and "what for", human being is in need of the Qur'an: divine knowledge and the meaning. The man, the universe and what happens around them only makes sense with the explanations of the Qur'an. In this regard, the Qur'an is the interpreter and the translator of the book of the universe.

"It is the eternal translation of the universe, the everlasting translator of the "languages" expressing the Divine Being's "natural" signs, the interpreter of the Book of the Universe. It discloses the secrets of the Divine Names' treasuries hidden on the "pages" of the heavens and Earth, and the key to the truths behind events" (Nursi, Mesnevii Nuriye, 1994: 230).

"The All-Wise Qur'an speaks of the universe in order to make known the Divine Essence, attributes, and Names. That is, it explains the meanings of the book of the universe to make known its Creator. That means it looks at beings, not for themselves, but for their Creator. Also, it addresses everyone. But philosophy and science look at beings for themselves, and address scientists in particular. In which case, since the All-Wise Qur'an makes beings evidences and proofs, the evidence has to be superficial so that it will be quickly understood in the general view. And since the Qur'an of Guidance addresses all classes of men, the ordinary people, which form the most numerous class, want guidance which is concise with unnecessary things being vague, and which brings subtle things close with comparisons, and which does not change things which in their superficial view are obvious into an unnecessary or even harmful form, lest it causes them to fall into error. For example, it says about the sun: "The sun is a revolving lamp or lantern." For it does not speak of the sun for itself and its nature, but because it is a sort of mainspring of an order and centre of a system, and order and system are mirrors of the Maker's skill." (Nursi, Mesnevi-i Nuriye, 1994: 230) (Nursi, 242, The Words, 1998: 251).

"Yes, the All-Wise Qur'an is a most elevated expounder, a most eloquent translator of the Mighty Qur'an of the Universe. Yes, it is the Criterion which instructs man and the jinn concerning the signs of creation inscribed by the pen of power on the pages of the universe and on the leaves of time. It regards beings, each of which is a meaningful letter, as bearing the meaning of another, that is, it looks at them on account of their Maker. It says, "How beautifully they have been made! How exquisitely they point to their Maker's beauty!", thus showing the universe's true beauty." (Nursi, 131, The Words, 1998: 145).

"In order to display His perfections, His beauty, and the truths of His Names, the Pre-Eternal Inscriber has written the universe in such a way that all beings set forth and state His infinite perfections, Names, and attributes together with their innumerable facets and aspects. Of course, if a book's meaning remains unknown, its value is reduced to nothing. However, a book like the universe, every word of which contains thousands of meanings, cannot lose its value or be made to do so" (Nursi, 575, The Words, 1998: 601).

"Infinitely perfect beauty and infinitely beautiful perfection want to behold themselves and show and exhibit themselves. In consequence of this, in order to make Himself and His perfections known, and to display His beauty and make Himself loved the Pre-Eternal Inscriber of the mighty book of the universe makes known and loved the beauty of His perfection and perfection of His beauty with the universe and all its pages, lines and even letters and points, with the innumerable tongues of all beings from the most particular to the most universal" (Nursi, 312, The Flashes, 1998: 401).

"Since a meaningful book requires a teacher to explain it; and an exquisite beauty requires a mirror to show itself and see itself; and a perfect work of art requires a herald to announce it; for sure among mankind, who is addressed by the mighty book of the universe, in every letter of which are hundreds of meanings and instances of wisdom, will be a perfect guide, a supreme teacher. For he will teach the sacred, true wisdom in the book; that is, make known the existence of the wisdom and purposes in the universe; indeed, be the means of the appearance, and even existence, of the dominical purposes in the universe's creation; and make known and act as a mirror to the perfect art of the Creator, and the beauty of His names, which $\mathrm{He}$ willed to display throughout the universe, showing their importance" (Nursi, 316, The Flashes, 1998: 406).

In that case, conceptually the main theme of this book of the universe is to introduce the author and manifest His attributes. One who can understand the systematic construction of the universe (from atoms to galaxies) and perceive the intention in its transformation and progress, realises that the writer would address and speak to human being and explain them why they were created. Nursi stated this meaning in his books as follows:

"Behind the veil of the Unseen is one who wants to make himself known through all these numerous finely adorned artefacts full of art in this corporeal Manifest World, and to make himself loved through these infinite sweet and decorated bounties, and to make known his hidden perfections through these innumerable miraculous and skilful works of art, and who does this by act rather than speech and by making himself known by the tongue of disposition. Since this is so, of a certainty he will speak and make himself known and loved through speech and utterance just as he does through deed and state. In which case, from his manifestations we must know him in respect to the World of the Unseen. Whereupon he entered that world with his heart and saw the following with the eye of his intellect:

The truth of revelations prevails at all instants over all parts of the World of the Unseen, with a most powerful manifestation. There comes with the truths of revelation and inspiration proceeding from the One All-Knowing of the Unseen, a testimony to His existence and unity far stronger than testimony of the universe and created beings. He does not leave Himself, His existence and His unity, only to the testimony of His creatures. Rather, He speaks with a pre-eternal Speech consonant with His own being. The Speech of the One Who is all-present and all-seeing everywhere with His Knowledge and Power is also endless, 
and just as the meaning of His Speech makes Him known, so does His discourse make Himself known together with His attributes.

The traveller recognized that the truth, reality, and existence of revelation has been made plain to the point of being self-evident by the consensus of one hundred thousand prophets (Peace be upon them), by the agreement among their proclamations concerning the manifestion of Divine revelation; by the evidences and miracles contained in the sacred books and heavenly pages, which are the guides and exemplars of the overwhelming majority of humanity, confirmed and assented to by them, and are the visible fruits of revelation"(Nursi, 123, The Rais, 1998: 146-147).

"The Possessor and Master of the universe surely does everything with knowledge, disposes every affair with wisdom, directs everything all-seeingly, treats everything all-knowingly, and arranges everything willing the instances of wisdom, purposes, and benefits that are apparent in them. Since, then, the One who creates knows, surely the One who knows will speak. Since He will speak, surely He will speak to those who possess consciousness and thought, and those who will understand His speech. Since He will speak to those who possess thought, surely he will speak to mankind, whose nature and awareness are the most comprehensive of all conscious beings. Since $\mathrm{He}$ will speak to mankind, surely He will speak to the most perfect of mankind and those most worthy of address. Since He will speak to those who are most perfect, most worthy of address, highest in morality, and who will guide humanity; He will certainly speak to Muhammad, who, as friend and foe alike testify, is of the highest disposition and morality, who is obeyed by one fifth of humanity, to whose spiritual rule half of the globe has submitted, with the radiance of whose light the future of mankind has been illumined for thirteen centuries, to whom the believers, the luminous segment of humanity, renew five times daily the oath of allegiance, for whose happiness they pray, for whom they call down God's blessings and bear admiration and love in their hearts" (Nursi, 89, The Letters, 1998: 114-115).

It is the 'selfness' who reads, gathers information, understands and discovers new meanings. In his book "The Words", Nursi expresses that only understanding the nature of 'self' makes it possible to read the book of universe so to grasp its true meaning. The section on selfness in the Words discusses the history of philosophy, science and religion from the perspective of selfness. In the above mentioned collection, he starts with interpreting the following verses from the Qur'an regarding human beings:

"We did indeed offer the Trust to the heavens, and the earth, and the mountains; but they refused to undertake it being afraid thereof. But man assumed it; indeed, he is most unjust, most foolish" (Qur'an, 33:72).

Nursi suggests that one aspect of the precious trust, which heavens and mountains were afraid to bear is selfness. And, he continues as:

"Just as the 'l' is the key to the Divine Names, which are hidden treasures, so is it the key to the locked talisman of creation; it is a problem-solving riddle, a wondrous talisman. When its nature is known, both the 'l' itself, that strange riddle, that amazing talisman, is disclosed, and it discloses the talisman of the universe and the treasures of the Necessary World. The key to the world is in the hand of man and is attached to his self. For while being apparently open, the doors of the universe are in fact closed. God Almighty has given to man by way of a Trust, such a key, called the 'I', that it opens all the doors of the world; He has given him an enigmatic 'I' with which he may discover the hidden treasures of the Creator of the universe. But the 'I' is also an extremely complicated riddle and a talisman that is difficult to solve. When its true nature and the purpose of its creation are known, as it is itself solved, so will be the universe.

The All-Wise Maker gave to man as a Trust an 'l' which comprises indications and samples that show and cause to recognize the truths of the attributes and functions of His dominance, so that the 'I' might be a unit of measurement and the attributes of dominance and functions of Divinity might be known. However, it is not necessary for a unit of measurement to have actual existence; like hypothetical lines in geometry, a unit of measurement may be formed by hypothesis and supposition. It is not necessary for its actual existence to be established by concrete knowledge and proofs" (Nursi, 535-537, The Words, 1998: 558-560).

Being able to understand the universe in which one lives is the fundamental subject of the religion, philosophy and science. Each science and philosophy doctrine seeks to make sense of the universe and make relative judgements. A human being can solve mysteries of the $\mathrm{Na}-$ mes of the creator and the universe only if he comprehends his selfness, the "l". It is impossible for someone who does not know his own meaning to understand with his unknown selfness the meaning of the universe as well as the meanings of the Creator and his acts. When those are not known, selfness, the "l" is drowning in troubles and complications; all of the psychological struggles, philosophical crisis and problems caused by not making sense of the universe are originated from that. For example, Freud stated that it is necessary to understand selfness of human being in order to solve the problems resulted from the world wars. If selfness, which is the foundation of his nature, was burdened to human being by his Creator, and if $\mathrm{He}$ demanded that the universe and its owner be known, mysteries of those cannot be uncovered irrespective of selfness. Even the history of philosophy proves this fact. Bediüzzaman defines selfness as being the key to make sense of this. The Names of the creator are the hidden treasures and the key to these treasures is the selfness of human being. Selfness is also the key to the universe whose meanings are hidden and difficult to understand. Thus, selfness builds a connection between the Names of the creator and the universe. But, Nursi noted that it is difficult to comprehend the nature of this key. Nursi expressed that with knowing the nature of selfness these treasures will be uncovered, and the mysteries of the universe and the names of the Creator will be discovered. In doing so, Nursi provided new explanations in regards to the nature of selfness and made a new definition of selfness. He attributed a measurement of unit characteristic to selfness; comparison. Comparison is a law of reasoning, two things are compared with each other and the value of each will reveal. Human is an element of comparison; distance measurements $(\mathrm{km}$, mile) are made by comparison, weights are measured by comparison. Relativity of two things to each other is made by comparison. Comparison is an important instrument of science, such as a thermometer measuring the temperature and a barometer measuring the air pressure.

Nursi expands the discussion regarding the measurement of unit and answers the question of "Why is knowledge of the attributes and Names of God Almighty connected to selfness, the 'I'?" as follows:

"Since an absolute and all-encompassing thing has no limits or end, neither may a shape be given to it, nor may a 
form be conferred on it, nor may it be determined; what its quiddity is may not be comprehended. For example, an endless light without darkness may not be known or perceived. But if a line of real or imaginary darkness is drawn, then it becomes known. Thus, since God Almighty's attributes like knowledge and power, and Names like AllWise and All-Compassionate are all-encompassing, limitless, and without like, they may not be determined, and what they are may not be known or perceived. Therefore, since they do not have limits or an actual end, it is necessary to draw a hypothetical and imaginary limit. The 'l' does this. It imagines in itself a fictitious dominance, ownership, power, and knowledge: it draws a line. By doing this it places an imaginary limit on the all-encompassing attributes, saying, "Up to here, mine, after that, His;" it makes a division. With the tiny units of measurement in itself, it slowly understands the true nature of the attributes.

For example, the 'I' may understand the dominance of its Creator over contingent creation with its imagined dominance over what it owns. And with its apparent ownership, it may understand the true ownership of its Creator, saying: "Like I am the owner of this house, so too is the Creator the owner of the universe." And with its partial knowledge, it may understand His knowledge, and with its small amount of acquired art, it may understand the original art of the Glorious Maker. For example, the 'I' says: "As I made this house and arranged it, so someone must have made the universe and arranged it," and so on. Thousands of mysterious states, attributes, and perceptions which make known and show to a degree all the Divine attributes and functions are contained within the ' $I$ '.

That is to say, the 'I' is mirror-like, and, like a unit of measurement and tool for discovery, it has an indicative meaning; having no meaning in itself, it shows the meaning of others. It is a conscious strand from the thick rope of the human being, a fine thread from the raiment of the essence of humanity, it is an Alif from the book of the character of mankind, and it has two faces" (Nursi, 535-537, The Words, 1998: 558-560).

Since the Creator is absolute, the limited potential of a human being cannot comprehend him. The Creator has attached keys to the selfness of human being who wishes to understand Him and demanded that those keys be known and used. The possession of the Creator is an absolute possession, whereas human's possession is a virtual image. Power and wisdom are illusions for human beings, it is power and wisdom which are granted and can be taken back. But, the right of disposition for power and wisdom are granted to human only for temporarily. Namely, anything that a human holds has been granted to him; nothing is under his ownership; yet, his ability to compare is in just a form of assumption and illusion. Hypothetical and imaginary comparisons made by reason make it possible to know the Creator's attributes and acts. Because, human can make a hypothetical comparison only with values he holds. These are elements just like the hypothetical lines in geometry (e.g., latitude, longitude). Nursi explains the comparison between the absolute and hypothetical. Absolute is something that cannot be measured, has no boundaries, is not bound to any terms, is limitless; therefore, it is impossible to be known. As an example, he says that light cannot be known in the absolute brightness where there is no presence of darkness.

Continuing, Nursi adds that the selfness whose nature is not comprehended and that is not properly used will not be able to make sense of the universe, and bring it to the point of a monster who would destroy the universe where it lives, massacre itself and its kind.
"The real nature of the ' $l$ ' is indicative; it shows the meaning of things other than itself. Its dominance is imaginary. Its existence is so weak and insubstantial that in itself it cannot bear or support anything at all. Rather, it is a sort of scale or measure, like a thermometer or barometer that indicates the degrees and amounts of things; it is a measure that makes known the absolute, all-encompassing and limitless attributes of the Necessary Being. He truly carries out the Trust, and through the telescope of his 'I', he sees what the universe is and what duties it is performing. When he obtains information about the universe, he sees that his 'I' confirms it. This knowledge will remain as light and wisdom for him, and will not be transformed into darkness and futility. When the 'l' fulfils its duty in this way, it abandons its imaginary dominance and supposed ownership, which are the units of measurement, and it says: "His is the sovereignty and to Him is due all praise; His is the judgement and to Him will you all be brought back."

Indeed, if the 'I' is not known for what it is, an insubstantial Alif, a thread, a hypothetical line, it may burgeon in concealment under the ground, gradually swelling. It will permeate all parts of a human being. Like a gigantic dragon it will swallow up the human being; that entire person with all his faculties will, quite simply, become pure 'I'.

Then too, the 'I-ness' of the human race gives strength to the individual 'I-ness' by means of human racialism and national racialism, and the 'I', gaining support from the 'Iness' of the human race, contests the commands of the Glorious Maker, like Satan.

Thus, while in this treacherous position, the 'l' is in absolute ignorance. Even if it knows thousands of branches of science, with compounded ignorance it is most ignorant. For when its senses and thoughts yield the lights of knowledge of the universe, those lights are extinguished because such an 'I' does not find any material within itself with which to confirm, illuminate, and perpetuate them. Whatever it encounters is dyed with the colours that are within it. Even if it encounters pure wisdom, the wisdom takes the form, within that 'I', of absolute futility. For the colour of an 'l' that is in this condition is atheism and ascribing partners to God, it is denial of God Almighty. If the whole universe is full of shining signs, a dark point in the 'I' hides them from view, as though extinguished" (Nursi, 535-537, The Words, 1998: 558-560).

Human being is being tested with his selfness. Considered being a key to understand the beautiful names of the Creator and enter into that realm, selfness faces with the paradox of reaching to a point where "claim over possession and never become satisfied regardless of how much he possesses". Hypothetical and relative forces are being used to claim possession which is far from their main goals. Granted for the purpose of promoting to the higher levels of humanity in towards understanding the Creator, the "I" may turn him into an unmerciful ignorant.

\section{Conclusion}

Nursi declares that Risale-i Nur had neither been derived from the wisdom of the East nor from the science of the West. He shows that Risale-i Nur reveals the significance of concepts and the true meanings of the universe when explained with direct inspiration from the Qur'an versus solely by humans' deduction. In this regard, it is neither a repetition of the old thoughts nor a by-product of scientific methods. Perceiving the knowledge and observation as the pages and the words from the book of universe, Nursi makes a direct connection between the Qur'an and the universe. By doing so, he proves that there is no contradiction whatsoever in between the two, and as 
a matter of fact they both are inscribed by the same author. Therefore, when 'selfness' is properly employed, it will become apparent to man that what the book of universe tells is no different than the revelation indeed. When the nature of 'selfness' is known and utilized as described, it offers a perception which does not disregard the products of the philosophical and scientific approaches, but rather interprets them in the light of the revelation turning all information into wisdom. Nursi's definition of existence is shaped within the framework of four main concepts: one bearing the meaning of another, one being as signifying itself, intention and perception. Within this framework, regarding the nature of human being and its selfness, the "I" is attributed as the key to decrypt the book of universe.

\section{REFERENCES}

Anstey, Peter (2010). ESP is best. In: Early Modern Experimental Philosophy (Project). Retrieved from https://blogs.otago.ac.nz/ emxphi/2010/09/esp-is-best/
Campbell, J (1995). The body image and self-consciousness. In J. L. Bermúdez, A.J. Marcel, \& N. Eilan (Eds.), The body and the self. The MIT Press, 29-42.

Loeb, Luis E. (1981). From Descartes to Hume: Continental Metaphysics and the Development of Modern Philosophy, Ithaca, Cornell University Press.

Nursi, Bediüzzaman Said (1998). The Flashes [Lem'alar]. Sözler Publications.

Nursi, Bediüzzaman Said (1998). The Letters [Mektubat]. Sözler Publications.

Nursi, Bediüzzaman Said (1998). The Rays [Şualar]. Sözler Publications.

Nursi, Bediüzzaman Said (1998). The Words [Sözler]. Sözler Publications.

Nursi, Bediüzzaman Said (Envar Nesriyat, 1994). Mesnevi-i Nuriye: 230.

Qur'an, 33:72.

Russell, G. A. (Ed.) (1993). The 'Arabick' Interest of the Natural Philosophers in Seventeenth-Century England. Brill: 224-262. DOI: https://doi.org/10.1163/9789004247062

Бюлент Гюзель,

Йилдиз технічний університет (м. Стамбул, Туреччина)

e-mail: bcguzel@gmail.com,ORCID 0000-0001-6915-4209

\section{У САМОСТІ ("Я") КЛЮЧ ДО ВСЕСВІТУ}

На підставі ретроспективного аналізу міркувань про знання та віру визначних представників європейської філософії автор статті підводить читача до думки, що Всесвіт є "вмістилищем" значень про світ, і одним 3 джерел винаходження цих значень є релігія. Далі він показує, що джерелом інтерпретації смислів та отримання нових значень в Ісламській традиції є збірка "Рісале-і Нур" турецького богослова Бадіуззамана Саїда Нурсі. у "Рісале-і Нур" запропоновано нове розуміння характеру відносин між Кораном - книгою "Божественного атрибуту мови" - та Всесвітом - книгою Сили "Божественного атрибуту Волі". Бадіуззаман постійно звертає увагу читачів на Всесвіт, демонструючи, як "читати" його за допомогою куранської методології, як зрозуміти вічний сенс, на який вказує творення, і як дійти до висновків, зазначених у Корані. Аналізуючи конкретні томи "Рісале-і Нур" (зокрема "Слова", "Листи", "Спалахи", "Промені"), автор статті показує оригінальність міркувань Саїда Нурсі, які не походять ані від мудрості Сходу, ані від науки Заходу. Доводиться, що "Рісале-і Нур" розкриває значення понять та справжніх значень Всесвіту прямим натхненням з Корану, а не лише на підставі раціональних умовиводів. Сприймаючи знання та спостереження як сторінки та слова 3 книги Всесвіту, Нурсі здійснює прямий зв'язок між Кораном та Всесвітом. Тим самим він доводить, що між ними немає суперечності, і фактично вони обидва написані одним автором. Отже, коли "самість" ("Я") задіяна належним чином, людині стає очевидним, що те, про що розповідає книга Всесвіту, нічим не відрізняється від одкровення. Визначення Саїда Нурсі існує в рамках чотирьох основних понять: одне носить сенс іншого, одне - яке означає себе, наміри та сприйняття. Коли природа "самості" відома і використовується як описано, вона пропонує сприйняття, яке не нехтує продуктами філософського та наукового підходів, а швидше інтерпретує їх у світлі одкровення, перетворюючи всю інформацію на мудрість. Тому ключ до розшифровки книги Всесвіту криється в природі людини та її самості.

Ключові слова: самість; Всесвіт; Рісале-і Нур; Коран.

(c) Bülent Güzel

Надійшла до редакції: 01.05.2020

Прийнята до друку: 25.05.2020 